\title{
Téoros
}

Revue de recherche en tourisme

\section{Le chemin le moins fréquenté}

Tourisme et innovation : le réseau de connaissances de l'OMT

The Road Less Travelled

Tourism and Innovation: The UNWTO Knowledge Network

\section{Eduardo Fayos-Solà}

Volume 30, numéro 1, 2011

URI : https://id.erudit.org/iderudit/1012117ar

DOI : https://doi.org/10.7202/1012117ar

Aller au sommaire du numéro

Éditeur(s)

Université du Québec à Montréal

ISSN

0712-8657 (imprimé)

1923-2705 (numérique)

Découvrir la revue

Citer cet article

Fayos-Solà, E. (2011). Le chemin le moins fréquenté : tourisme et innovation : le réseau de connaissances de l'OMT / The Road Less Travelled: Tourism and Innovation: The UNWTO Knowledge Network. Téoros, 30(1), 143-147.

https://doi.org/10.7202/1012117ar d'utilisation que vous pouvez consulter en ligne. 
CENTRE INTERNATIONAL DE FORMATION

ET DE RECHERCHE EN TOURISME

\section{Le chemin le moins fréquenté Tourisme et innovation : le réseau de connaissances de l'OMT}

\author{
Eduardo FAYOS-SOLÀ ${ }^{1}$ \\ Secrétaire exécutif du réseau de connaissances de l'OMT \\ Professeur d'économie, Universidad de Valencia \\ efsola@unwto.org
}

INTERNATIONAL CENTRE FOR EDUCATION AND RESEARCH IN TOURISM

\author{
Eduardo FAYOS-SOLÀ ${ }^{1}$ \\ Executive Secretary of the UNWTO Knowledge Network \\ Professor of Economics, Universidad de Valencia \\ efsola@unwto.org
}

\begin{abstract}
« Deux chemins divergeaient dans un bois, Et moi, j'ai pris le chemin le moins fréquenté, Et cela a fait toute la différence. » (Traduction libre) Robert Frost, 1916
\end{abstract}

\section{Contexte}

À l'image du voyageur anonyme de Frost, le tourisme contemporain se trouve à la croisée des chemins. L'un des chemins traverse un paysage maintes fois parcouru, jonché de produits et de méthodes par trop familiers; le tourisme du $20^{\mathrm{e}}$ siècle, tributaire des énergies fossiles bon marché, achèvera bientôt son cycle de vie.

Toutefois, à mesure que cette ère tire à sa fin, il s'agit de se demander si le tourisme est moribond ou s'il y a moyen, en empruntant une voie moins fréquentée, de le transformer en un vecteur de connaissances, de développement, de durabilité et d'une meilleure macrogouvernance.

Les défenseurs du modèle touristique du «comme si de rien n'était» soutiennent que le tourisme est un extraordinaire véhicule d'allègement de la pauvreté, voire de développement. Ils admettent, certes, que tourisme et gaspillage vont de pair, que cette activité a un impact environnemental indéniable et que ses effets secondaires sont parfois des plus indésirables. Or, vu l'échec des autres instruments de création d'emplois, de revenus et de croissance économique, il se peut que le tourisme traditionnel permette encore d'améliorer le sort des collectivités et des pays pauvres.

Cependant, commençons par examiner la confusion fréquente entre «croissance» et «développement». À quelques notables exceptions près, nous restons obsédés par la croissance du PIB, que nous assimilons à la prospérité et au bienêtre. Néanmoins, à mesure que naît une nouvelle société, il convient de réaliser que le développement dépend au moins autant des connaissances, du capital institutionnel et de la gouvernance participative que du «capital traditionnel », qu'il soit physique ou financier. C'est seulement l'accumulation du
"Two roads diverged in a yellow wood... I took the one less travelled by, And it has made all the difference."

Robert Frost, 1916

\section{Background}

Like Frost's anonymous traveller, contemporary tourism is at a crossroads. One of the roads is just going down a trodden landscape of déjà-vu products and methods; $20^{\text {th }}$ century tourism is a product of fossil-fuel era low-cost energy, and has exhausted much of its life-cycle.

But as that era comes to an end, we may start thinking whether tourism is doomed or if, perhaps, it can be transformed into a vector for knowledge, development, sustainability and better macro-governance. A less travelled road.

Defenders of tourism-as-usual have argued that tourism is an extraordinary vehicle for the alleviation of poverty, and even for development. Yes, they admit, tourism may be wasteful, it does impact the environment, and it may have very undesirable secondary effects. But other instruments for the creation of employment, of incomes, of economic growth having failed, it might still be that traditional tourism offers a way of improving the lot of poor communities and nations.

However, let's first consider how often growth has been confused with development. With notable exceptions, we are still obsessed with GDP increases, which we equate with prosperity and well-being. But, as a new society is born, we should become increasingly aware that development is in fact at least as dependent on knowledge, institutional capital and participatory governance as it is on physical and financial, conventional capital. It is only the accumulating human and social capital that has somehow counteracted an accelerated concentration of conventional capital and subsequent monopoly of power in elites. Recent geopolitical events back this observation. 
capital humain et social qui a réussi, d'une manière ou d'une autre, à faire contrepoids à la concentration accélérée du capital traditionnel entre les mains des élites et au monopole du pouvoir qui s'ensuit; les récents événements géopolitiques confirment par ailleurs ces observations.

Ce sont les connaissances qui, en réalité, nourrissent la croissance d'un capital humain et social plus également réparti. Ces connaissances, très souvent gratuites, décuplent notre créativité et entraînent une hausse de la participation et de la qualité au sein de nos institutions. C'est également aux connaissances que l'on doit l'accroissement de la productivité économique et l'amélioration générale des normes scientifiques, technologiques et éducatives.

Ainsi, il existe assurément des arguments appuyant l'affirmation selon laquelle le tourisme est un véhicule de développement, outre le fait que tout investissement privé dans le tourisme vise à générer des profits. Ces derniers ont tendance à entraîner des retombées sous forme d'emplois, de revenus et de formations supplémentaires. Évidemment, les investissements nets en tourisme produisent de la croissance... mais du «développement »? La croissance du capital socio-institutionnel et humain que l'on associe normalement au développement se produira seulement si les investissements en tourisme portent explicitement sur la production, la diffusion et l'application de connaissances. En somme, la gestion des connaissances et l'innovation en tourisme seraient non seulement des conditions préalables à la rentabilité et à la compétitivité, mais bien les conditions sine qua non d'un développement mû par le tourisme.

C'est dans un tel cadre que l'Organisation mondiale du tourisme (OMT) des Nations Unies a récemment lancé le Réseau des connaissances de l'OMT. Ce lancement a été réalisé à la lumière du fait implicite que la gestion des connaissances est non seulement un instrument essentiel de compétitivité et, ultimement, de survie, mais la clé d'un nouveau paradigme touristique dont les objectifs ambitieux concernent le développement, l'atténuation des changements climatiques et l'excellence en macrogouvernance.

L'OMT a développé au fil des ans une grande capacité de coordination en matière de prise de décisions politiques sur des questions stratégiques intéressant les activités touristiques dans le monde entier. Ensuite, le tourisme ayant acquis une pertinence accrue dans les affaires mondiales, sa nature transversale en fait un élément essentiel de la gestion des connaissances dans une variété de domaines, qui vont d'enjeux micro-économiques touchant les transports, l'hébergement et les divertissements, jusqu'aux objectifs du Millénaire de l'ONU pour le développement. Ainsi, l'OMT doit impérativement s'investir dans la gestion des connaissances sous toutes ses formes et entreprendre, à l'échelle mondiale, une mise en commun des connaissances liées au tourisme. Cette base de savoir viendra désormais appuyer la capacité avérée de l'OMT en matière de prise de décisions politiques.

Cela s'inscrit, bien entendu, dans la lignée du programme de travail de plusieurs institutions des Nations Unies, telles que la FAO, l'OMS et l'UNESCO, qui ont établi des réseaux de connaissances étendus dans leurs champs de compétences respectifs. L'OMT est devenue en 2003 un organe spécialisé
And it is knowledge that is really feeding the growth of more equally spread human and social capital. It is knowledge, very often for free, that is multiplying our creativity, improving participation and quality in our institutions. It is knowledge as well that is resulting in increased economic productivity and an environment of raised standards for science, technology and education.

Thus, when contending that tourism is a vehicle for development, there must surely be a rationale beyond the fact that any private investment in tourism is made with profit generation in sight and that this profit may trickle down in the way of some added employment, income and training. Of course net investments in tourism produce growth... but development? The increase in social-institutional and human capital normally associated with development will come only if tourism investments are explicitly dealing with the production, dissemination and application of knowledge. In short, knowledge management and innovation in tourism may not only be a pre-requisite for profitability and competitiveness; it may well be a sine-qua-non condition for tourism-led development.

It is in this framework, that the United Nations World Tourism Organization (UNWTO) has recently launched the UNWTO Knowledge Network initiative. This has been done in the implicit understanding that knowledge management is not only an essential instrument for competitiveness and ultimate survival, but the key to a new tourism paradigm with ambitious objectives of development, mitigation of climate change and excellence in macro-governance.

UNWTO has developed over the years a considerable capacity to coordinate political decision making in policy issues relevant to tourism activities worldwide. Then, as tourism has become increasingly relevant in world affairs, its transversal nature has made it essential to interact with knowledge management in a variety of areas, ranging from microeconomic issues of transportation, accommodation and entertainment to the UN Millennium Development Goals. Thus UNWTO must now crucially involve itself in all matters of knowledge management and create a permanent Global Community of Knowledge related to Tourism. The proven political decision-making capacity of UNWTO is now to be fostered by this community of knowledge.

This is of course in line with the programme of work of several specialised agencies of the United Nations such as FAO, WHO or UNESCO, which have created extensive knowledge networks in their respective fields of competence. The former WTO (World Tourism Organisation) became itself a UN specialised agency in 2003 and joined the UN Group of Knowledge Management Initiatives in 2006. UNWTO Member States now consider tourism policy not only of sectoral interest but, as commented, also an essential instrument for key transversal public policies.

\section{The UNWTO Knowledge Network}

The UNWTO Knowledge Network is a special programme of the Organisation, under the direct leadership of the UNWTO Secretary-General. Its purpose is to develop and manage a worldwide association of UNWTO Tourism Think Tanks 
des Nations Unies qui s'est joint en 2006 au groupe d'initiatives de gestion des connaissances de l'ONU. Les États membres de l'OMT considèrent que la politique touristique relève non seulement d'un intérêt sectoriel, mais également, comme nous l'avons indiqué, qu'elle est un instrument essentiel pour l'élaboration de politiques publiques transversales clés.

\section{Réseau de connaissances de l'OMT}

Le réseau de connaissances de l'OMT est un programme spécial, placé sous l'autorité directe du Secrétaire général de l'OMT. Le rôle du réseau de connaissances de l'OMT est de développer et de gérer une association mondiale de groupes de réflexion sur le tourisme (UNWTO Tourism Think Tanks, ou TTT), de centres stratégiques de connaissances (UNWTO Knowledge Strategic Centers) et d'institutions de connaissances (UNWTO Knowledge Institutions), et d'établir des normes de recherche et de gestion des connaissances concernant l'analyse du tourisme, les politiques touristiques et la gouvernance du tourisme. Les TTT nationaux et régionaux et les centres stratégiques et institutions de connaissances de l'OMT, qui forment ensemble le réseau de connaissances de l'OMT, servent l'Organisation et ses États membres pour tous conseils techniques et décisionnels dans les domaines de la viabilité et du changement climatique, de l'innovation en matière de produits et de procédures, de la compétitivité et de l'excellence dans la gouvernance du tourisme. Les TTT nationaux et régionaux sont formés par des institutions et des organisations du secteur public et du secteur privé, notamment des universités, des centres de recherche, des parcs scientifiques et technologiques et des entreprises privées ayant des activités dans la recherche et l'innovation. Les centres stratégiques et les institutions de connaissances de l'OMT sont des organisations autonomes. Le réseau de connaissances de l'OMT prend activement part aux comités et organes de l'OMT adéquats, ainsi qu'aux projets de l'OMT pour lesquels une expertise technique et des compétences en matière de gestion des connaissances représentent une valeur ajoutée considérable.

\section{Mission et objectifs}

La mission du réseau de connaissances de l'OMT est la suivante :

"Apporter son soutien à l'OMT et à ses États membres sur toutes les questions relatives à la science, la technologie, l'innovation et la gestion des connaissances en rapport avec les opérations, la politique et la gouvernance touristiques, en vue de contribuer à assurer la compétitivité du secteur et à réaliser les objectifs de développement mondiaux définis par les Nations Unies et d'autres institutions internationales de gouvernance».

Les objectifs du réseau de connaissances de l'OMT sont les suivants : (i) créer une communauté de connaissances sur des questions liées au tourisme, afin de contribuer à la compétitivité, à la durabilité, au développement et à la bonne gouvernance; (ii) créer une réserve de recommandations, de meilleures pratiques, de normes volontaires, de codes et de normes constituant un Codex Turismus pouvant s'appliquer largement aux opérations, à la politique et à la gouvernance dans le tourisme et les domaines connexes; et (iii) participer
(UNWTO.TTTs), UNWTO Knowledge Strategic Centres and UNWTO Knowledge Institutions, setting research and knowledge management procedures and standards on tourism analysis, tourism policy and tourism governance. The national and regional UNWTO.TTTs, Knowledge Strategic Centres and Knowledge Institutions, grouped in the UNWTO Knowledge Network, serve the Organisation and its Member States in all matters concerning technical advice and decisions in the areas of sustainability and climate change, innovation in products and procedures, competitiveness and excellence in tourism governance. The national and regional UNWTO.TTTs are consortia formed by institutions and organisations from the public and private sector, including universities, research centres, scientific and technological parks, private companies and clusters active in research and innovation. The UNWTO Knowledge Strategic Centres and UNWTO Knowledge Institutions are self-standing organisations. The UNWTO Knowledge Network participates actively in all pertinent UNWTO Committees and bodies, as well as in UNWTO projects, where technical expertise and knowledge management capacities add substantial value.

\section{Mission and objectives}

The mission of the UNWTO Knowledge Network is thus defined as follows: «To support UNWTO and its Member States in all matters concerning Science, Technology, Innovation and Knowledge Management related to Tourism Operations, Tourism Policy and Tourism Governance, with a view to contribute to sectoral competitiveness and global development objectives as defined by the United Nations and other international institutions of governance».

The objectives of the UNWTO Knowledge Network are (i) to create a Community of Knowledge in matters relating to Tourism, contributing to competitiveness, sustainability, development and good governance; (ii) to create a repository of recommendations, best practices, voluntary standards, codes and norms constituting a Codex Turismus, with wide applications for operations, policy and governance in tourism and related fields; and (iii) to proactively participate in the creation, dissemination and application of knowledge related to tourism, whether in the UNWTO Programme of Work or in projects launched or financed by other institutions or organisations.

\section{Structure}

The UNWTO Knowledge Network is built upon accomplishments of the former UNWTO Education and Science Council and is made up of the following classes of members:

UNWTO Knowledge Institutions. These are institutions or organisations with a knowledge management capacity that may become formally involved in UNWTO through Affiliate Membership and collaborate with UNWTO in the implementation of its Programme of Work. The UNWTO Knowledge Institutions may thus enjoy all the regular benefits of Affiliate Members and also those specific to the UNWTO Knowledge Network. In the transitional stage, all members of the former Education and Science Council may automatically become UNWTO Knowledge Institutions. 
de manière proactive à la création, à la diffusion et à l'application de connaissances liées au tourisme, soit dans le cadre du Programme de travail de l'OMT, soit dans des projets lancés ou financés par d'autres institutions ou organisations.

\section{Structure}

Le réseau de connaissances de l'OMT est basé sur les réalisations de l'ancien Conseil de l'éducation et de la science de l'OMT et est composé de la manière suivante :

Institutions de connaissances de l'OMT : Ce sont des institutions ou des organisations dotées de capacités de gestion des connaissances qui rejoignent l'OMT en tant que membres affiliés et collaborent avec elle dans l'exécution de son programme de travail. Les institutions de connaissances de l'OMT jouissent de tous les avantages habituels des membres affiliés ainsi que de ceux propres au réseau de connaissances de l'OMT.

Au cours de la transition, tous les anciens membres du Conseil de l'éducation et de la science pourront automatiquement devenir des institutions de connaissances de l'OMT.

Centres stratégiques de connaissances de l'OMT : Ce sont des institutions ou des organisations certifiant que l'innovation représente une partie importante de leurs fonctions et de leur structure. Elles peuvent devenir des centres stratégiques de connaissances de l'OMT en se soumettant à un processus de certification officielle. Elles participent de façon permanente à des programmes et à des projets particuliers de l'OMT et peuvent diriger un TTT.

Groupes de réflexion sur le tourisme de l'OMT (TTT) : Un TTT est une institution dotée de la capacité juridique et composée d'au moins un centre stratégique de connaissances et éventuellement d'autres institutions, organisations et entreprises du secteur privé ou public appartenant au réseau de connaissances de l'OMT ou collaborant avec lui. Les TTT occupent une place centrale au sein du réseau de connaissances de l'OMT, et servent sa mission et ses objectifs en fournissant des services à l'OMT au niveau national, régional et mondial, et à la communauté de connaissances de l'OMT, y compris à tous ses membres. Les TTT coordonnent leurs actions au sein de l'OMT par l'intermédiaire du Secrétaire exécutif chargé de la science et de la gestion des connaissances affecté au cabinet du Secrétaire général et également par l'intermédiaire des directeurs régionaux.

\section{Membres et activités}

Depuis sa création à l'automne 2010, le Réseau de connaissances de l'OMT a attiré quelque 130 membres de plus de 40 pays. Les membres du réseau ouvrent au sein de programmes et de projets de recherche, de développement et d'innovation, dont certains abordent directement des enjeux propres au tourisme, alors que d'autres, nombreux, ont trait à des actions dans une variété de domaines étendus, notamment l'énergie, l'architecture, le design, la conservation de la nature, le droit et la science et technologie en général.

Le Réseau de connaissances de l'OMT a tenu sa réunion de lancement en janvier 2011 à Madrid. Cette réunion a fourni aux membres (dont 110 étaient présents) une première occasion de se rencontrer en personne et de procéder à la définition
UNWTO Strategic Centres. These are institutions or organisations properly accredited for having innovation as an important part of their functions and structure. They may become UNWTO Knowledge Strategic Centres by submitting to a process of formal accreditation. They are permanently involved in specific UNWTO programmes and projects and may lead a UNWTO Tourism Think Tank.

UNWTO Tourism Think Tanks (UNWTO.TTTs). A UNWTO.TTT is a consortium with a legal capacity to act, made up of at least one UNWTO Knowledge Strategic Centre and other institutions, organisations and enterprises whether in the private or public sector, belonging or collaborating with the UNWTO Knowledge Network. The UNWTO.TTTs occupy hub positions within the UNWTO Knowledge Network and serve its mission and objectives by providing services to UNWTO at national, regional and global level as well as to the UNWTO Community of Knowledge, including all its Members. The UNWTO.TTTs coordinate their actions in UNWTO through the Executive Secretary for the UNWTO Knowledge Network in the Office of the Secretary General and through the Regional Directors.

\section{Members and activities}

Since its inception, in the autumn of 2010, the UNWTO Knowledge Network has attracted some 130 members from over 40 countries. Network members are active in research, development and innovation programmes and projects, some of them directly addressing issues in tourism, but many others involving actions in a variety of wide fields, such as energy, architecture, design, nature conservation, law, and science and technology in general.

The UNWTO Knowledge Network held its kick-off meeting in January 2011 in Madrid. The meeting was the first occasion for Network members (some 110 attended) to meet personally and start establishing lines of operation. Several lines of research and innovation were presented on this occasion by Network members from the Americas, Asia-Pacific and Europe, ranging from climate change mitigation approaches to renewable energy solutions and design of $21^{\text {st }}$ century tourism destinations. This was intended as inspiration on road-maps for action and collaboration. Participants were able to introduce themselves and express their strategic views on innovations relating to tourism.

Then, in June 2011, the UNWTO Knowledge Network, in collaboration with the University of Algarve, held the Forum Tourism and Science: Bridging Theory and Practice, in Vilamoura, Portugal. The aim of the Forum was to achieve an informed consensus on tourism research and governance, setting a reference framework vis-à-vis the main strategic challenges that tourism faces today, chiefly development, climate change/sustainability, and participatory implementation of policies at public and private levels. The Forum was also concerned with ways and means regarding market positioning, product and process innovation, and competitiveness, among others. 
de certains secteurs d'activité. Plusieurs avenues de recherche et d'innovation ont ainsi été proposées par des membres du réseau provenant des Amériques, d'Asie-Pacifique et d'Europe, allant d'approches centrées sur l'atténuation des changements climatiques à des solutions en matière d'énergies renouvelables et à la conception des destinations touristiques du $21^{\text {e }}$ siècle. L'objectif était d'inspirer un plan d'action et d'encourager la collaboration. Les participants ont pu faire connaissance et échanger leurs points de vue stratégiques sur les innovations qui touchent le secteur touristique.

En juin 2011, le Réseau de connaissances de l'OMT, de concert avec l'université de l'Algarve, a tenu le forum Tourism and Science: Bridging Theory and Practice (Tourisme et science : allier la théorie à la pratique) à Vilamoura, au Portugal. Ce forum visait l'atteinte d'un consensus éclairé sur la recherche et la gouvernance en tourisme par l'établissement d'un cadre de référence axé sur les principaux défis stratégiques que le tourisme actuel doit relever, soit, en premier lieu, le développement, les changements climatiques/la durabilité et la mise en ouvre participative de politiques, tant sur les plans public que privé. Le forum s'est penché, en second lieu, sur les méthodes et les moyens novateurs relatifs au positionnement sur le marché, aux produits et aux procédés, et à la compétitivité, entre autres choses.

\section{Observations finales}

L'OMT, en répondant aux besoins de ses États membres, a reconnu que la gestion des connaissances constitue un facteur critique de réussite dans plusieurs domaines, qu'il s'agisse d'enjeux stratégiques liés au développement, à l'atténuation des changements climatiques et à une bonne macrogouvernance, ou de qualité et d'efficience des opérations, tant au sein des sociétés privées que dans le secteur public. La gestion des connaissances - soit le processus d'identification, de saisie, de partage et d'application du savoir - est devenue une stratégie de réussite et un élément nécessaire de la performance quotidienne. Le tourisme en soi est désormais une activité transversale ayant des répercussions énormes sur les politiques publiques en général et sur le bien-être des individus en particulier. Le concept de gestion des connaissances en tourisme mérite ainsi d'occuper une place centrale, d'une part, dans la conception et la mise en œuvre de politiques touristiques sectorielles, et, d'autre part, lorsqu'il s'agit d'aborder des enjeux tels que la création de revenus, l'emploi et, ultimement, le développement et la bonne gouvernance. Dans cette optique, l'OMT a créé son réseau de connaissances afin de répondre aux demandes croissantes de ses États membres et de l'industrie du tourisme dans son ensemble. Cette dernière se trouve à la croisée des chemins; les politiques et la gouvernance touristiques en sont au même point. Sans doute le moment est-il venu de prendre le temps de réfléchir un peu... et de s'engager sur le chemin qui, à ce jour, demeure «le moins fréquenté».

Note

1 L'auteur souhaite exprimer sa reconnaissance au professeur François Bédard, de l'UQAM, pour son aide lors de la préparation de ce document.

\section{Closing remarks}

UNWTO has recognised, in responding to the needs of its Member States, that knowledge management is a critical factor for success in many areas, ranging from strategic issues of development, mitigation of climate change and good macro-governance, to quality and efficiency at the operations level, both in private enterprises and in the public sector. Knowledge management-the process of identifying, capturing, sharing and applying knowledge- has become a success strategy as well as a requisite of everyday performance. In its own, tourism has become a transversal activity with enormous repercussions for public policies in general and private well-being in particular. Thus, the concept of knowledge management in tourism deserves a central positioning in the design and implementation of both sectoral tourism policy and when dealing with issues of income creation, employment and, ultimately, development and good governance. In this light, UNWTO has created its Knowledge Network to respond to growing demands of its Member States and the tourism industry in general. The tourism industry is at a crossroads; so is tourism policy and governance. It is perhaps the time to briefly ponder... and take the up-to-now less travelled road.

\section{Note}

1 The author wishes to express his recognition to Professor François Bédard at UQAM for his support in preparing this paper. 